\title{
Trends and Status of Agribusiness in Animal Husbandry of the Russian Federation
}

\author{
Alfiya KUZNETSOVA ${ }^{1}$, Marsel AVZALOV ${ }^{1}$, Denis GOGBUNOV ${ }^{1}$, Evgenii \\ STOVBA $^{2}$ \\ ${ }^{1}$ Bashkir State Agrarian University, Ufa, Russia \\ alfia 2009@mail.ru, m avzalov@mail.ru,den.83@inbox.ru \\ ${ }^{2}$ Bashkir State University, Birsk, Russia \\ stovba2005erambler.ru
}

\begin{abstract}
The article notes that agriculture in any country performs a socially significant task, providing the population with essential foodstuffs. Very often, agribusiness because of the large difference between the prices of industrial and agricultural products is low profitable or unprofitable. The identification of current trends and analysis of the current state of agribusiness in the livestock industry of the Russian Federation is the goal of this study. For the period from 2000 to 2017, the increase in the share of meat production in large-scale formations in them occurred in the country. In the structure of the concentration of livestock animals, there was an overflow of the number of livestock of domestic animals from large-scale to small-scale forms of management: especially cattle, cows, horses from agricultural organizations to peasant (farmer) farms. At present, the polarization of agricultural agri-formations is growing: on the one hand, the number of agricultural holdings is growing, on the other hand, the number of peasant (farmer) farms is increasing. There is a general reduction in the number of large livestock and an increase in the number of livestock of small domestic animals. Currently, strategic management decisions are needed to increase the level of food self-sufficiency of the population with meat, milk and meat and dairy products. It is very important to preserve the rural way of life, rural social infrastructure facilities, as well as rural jobs for $26 \%$ of rural residents of the country.
\end{abstract}

Keywords: Livestock, Forms of Management, Livestock, Livestock Structure, Production Structure.

\section{$1 \quad$ Introduction}

Agriculture has always occupied and occupies a special place in the economy of any country and is part of national security. Foreign and domestic experience shows that without active government intervention, its control over production and the level of security, timely measures of state support for agricultural producers, and assistance to them in the development of innovations, the industry will not be able to withstand priceto-sector imbalances. In Russia, with its variety of climatic and climatic conditions, 
temperature diversity, one of the main food products needed to maintain normal human activity is meat and meat products. This explains not only the choice of the research topic, but also its relevance.

The study of foreign experience clearly shows that on the one hand, in most countries of the world, urbanization contributes to a decline in the number of people who may have large domestic animals in their own farms or work in the public agricultural firms. On the other hand, the increase in gross domestic product and the growth of individual incomes, for example, contribute to higher demand for meat and meat products. This problem is successfully solved by the development of industrial livestock in some countries. However, this entails environmental problems, for the solution of which is devoted the works of scientists. Consider them in more detail.

According to Delgado C. [6], "cities will grow in the next few decades, especially in Africa and Asia," "urbanization has a significant impact on food consumption patterns in general and on demand for animal products in particular".

In the work of Philip K.Thornton [17] notes that "the demand for livestock products in the near future will only increase". According to Dijkman [7], "the development of the livestock industry is the only way to reduce poverty and over the past 20 years, few countries have effectively taken advantage of this opportunity".

In the work of Chinese scientists, it is said that "industrial production of beef is an essential part of livestock and meat production in China. China is the third largest beef producer in the world. Despite this, China's self-sufficiency in meat is not complete. According to Derrell S. Peel [5], Oklahoma State University Extension The main suppliers of beef to China in 2016 were Brazil (29\% of all Chinese imports), Uruguay (27\%), Australia (19\%), New Zealand (12\%), Argentina (9\%), other countries - 4\%. In 2017 , the import of beef to China was planned at the level of 950 thousand tons, which is $17 \%$ more than in 2016 ".

The growing demand for livestock products is growing with the growth of gross domestic product. In their work, Xiang, Zi Li., Chang, Guo Yan, Lin, Sen Zan [18] note, that "the Chinese beef industry faces technical problems, including the transformation of traditional production management, feeding systems, management, genetic improvement of cattle breeds".

In the work of Herrero M. et al [8], devoted to the study of intelligent investment in sustainable food production: a revision of mixed livestock systems "the author emphasizes that" in small-sized farms around the world, livestock is grown mainly on grass, biomass and non-food biomass from corn, millet, rice, sorghum, and manure, in turn, is directed at increasing the yields of future crops. " The author is absolutely right when he rightly notes that "animals act as insurance against hard times and are a regular source of income for farmers from the sale of milk, eggs and other products. With population growth and climate change, small farmers should be the first targets for policies aimed at enhancing production through well-managed resources (fertilizers, water, feed, and minimizing the environmental impact of waste".

In the work of scientists King D., Peckham C., Waage J.K., Brownlie J., Woolhouse M.E.J. [12] considered «factors that could influence the growth of infectious diseases that could cause harm to people, plants and animals", and "technological and political decisions" are needed to manage the situation». 
Worldwide, it is believed that animal husbandry causes serious environmental damage due to methane emissions, while animal husbandry accounts for $18 \%$ of the global anthropogenic emissions of this gas [11]. Some authors suggest "improving feeding methods, using specific agents or food additives"[16]. Beauchemin and McGinn [4] also write about this in their work, emphasizing that "the net benefit depends on a decrease in the number of animals, or earlier slaughter of animals (at a younger age)", as well as "through the use of more concentrates".

Some authors suggest adding oil to the animals 'diet to reduce methane production (for example, Machmülller A et al. [15]). Other authors suggest improving pasture quality for this purpose, especially in less developed regions (Alcock \& Hegarty [2]).

For the development of agriculture in Russia was devoted to the works of numerous Russian scientists, including our earlier works (Kuznetsova A.R. et al [3, 10, 13, 14]). Thus, scientists in different parts of the world solve the problems of livestock development, seeking the most rational technologies. The Russian agriculture has developed its own traditions and tendencies of doing business in animal husbandry. As everywhere, there are some positive aspects and problems.

\section{Trends and Status in Animal Husbandry in the Russian Federation}

The methodological basis of the study was general scientific research methods, interdisciplinary system-functional, statistical, computational-constructive, economicmathematical, graphical and other scientific approaches. We used tabular and graphical methods of statistical analysis of the main indicators for a comprehensive study of the problem.

The information base of the study was made up of official data from the Federal State Statistics Service of the Russian Federation, information resources of the global Internet and the results of its own research.

The aim of our study is to study the dynamics of changes in the structure of livestock production by the forms of management in the Russian Federation.

According to the Federal State Statistics Service of the Russian Federation, in the period from 2000 to 2017 in the Russian Federation, the number of livestock of agricultural animals underwent certain changes (Table 1).

Table 1. Livestock of farm animals in the Russian Federation in farms of all categories from 2000 to 2017 (thousand heads) [1,9].

\begin{tabular}{lcccccc}
\hline Indicators & $2000 \mathrm{y}$. & $2010 \mathrm{y}$. & $2015 \mathrm{y}$. & $2016 \mathrm{y}$. & $2017 \mathrm{y}$. & $\begin{array}{c}2017 \mathrm{y} . \\
\text { in \% } \\
\text { to 2000 y. }\end{array}$ \\
\hline Cattle & 27519.8 & 19967.9 & 18992.0 & 18752.5 & 18681.0 & 67.9 \\
cows & 12742.6 & 8843.5 & 8408.1 & 8263.7 & 8226.0 & 64.6 \\
Pigs & 15824.4 & 17217.9 & 21506.8 & 22027.7 & 23185.2 & 146.5 \\
Sheep and goats & 14961.9 & 21819.9 & 24881.1 & 24843.8 & 24489.8 & 163.7 \\
sheeps & 12730.5 & 19761.3 & 22713.1 & 22744.4 & 22401.4 & 176.0 \\
goats & 2231.4 & 2058.5 & 2168.1 & 2099.4 & 2088.4 & 93.6
\end{tabular}




\begin{tabular}{lcccccc}
\hline Indicators & $2000 \mathrm{y}$. & $2010 \mathrm{y}$. & $2015 \mathrm{y}$. & $2016 \mathrm{y}$. & $2017 \mathrm{y}$. & $\begin{array}{c}2017 \mathrm{y} . \\
\text { in \% } \\
\text { to } 2000 \mathrm{y} .\end{array}$ \\
\hline Horses & 1622.2 & 1340.6 & 1374.2 & 1381.3 & 1403.8 & 86.5 \\
Bird & 340665 & 449296 & 547195 & 553007 & 561281 & 164.8 \\
Reindeer & 1197.0 & 1571.0 & 1606.1 & 1650.8 & 1687.5 & 141.0 \\
Rabbits & 1276.7 & 2653.1 & 3721.2 & 3818.4 & 3909.8 & 306.2 \\
\hline
\end{tabular}

From the data presented in table 1 it follows that the number of cattle in the Russian Federation from 2000 to 2017 decreased by $32.1 \%$, cows - by $35.4 \%$, goats - by $6.4 \%$, horses - by $13.5 \%$.

The number of pigs in the farms of all categories of pigs increased by $46.5 \%$, sheep and goats - by $63.7 \%$ (including sheep - by $76 \%$ ), birds - by $64.8 \%$, northern deer - by $41 \%$, rabbits -3.1 times.

Consider the structure of the livestock of agricultural animals in the Russian Federation according to the forms of management in table 2 .

Table 2. The structure of the livestock of farm animals by forms of management in the Russian Federation for the period from 2000 to $2017[1,9]$.

\begin{tabular}{lcccccc}
\hline Indicators & $2000 \mathrm{y}$. & $2010 \mathrm{y}$. & $2015 \mathrm{y}$. & $2016 \mathrm{y}$. & $2017 \mathrm{y}$. & $\begin{array}{c}2017 \mathrm{y} . \\
\text { in } \% \\
\text { to } 2000 \mathrm{y} .\end{array}$ \\
\hline \multicolumn{7}{c}{ Agricultural organizations } \\
\hline Cattle & 27519.8 & 19967.9 & 18992.0 & 18752.5 & 18681.0 & 67.9 \\
cows & 12742.6 & 8843.5 & 8408.1 & 8263.7 & 8226.0 & 64.6 \\
Pigs & 15824.4 & 17217.9 & 21506.8 & 22027.7 & 23185.2 & 146.5 \\
Sheep and goats & 14961.9 & 21819.9 & 24881.1 & 24843.8 & 24489.8 & 163.7 \\
sheeps & 12730.5 & 19761.3 & 22713.1 & 22744.4 & 22401.4 & 176.0 \\
goats & 2231.4 & 2058.5 & 2168.1 & 2099.4 & 2088.4 & 93.6 \\
Horses & 1622.2 & 1340.6 & 1374.2 & 1381.3 & 1403.8 & 86.5 \\
Bird & 340665 & 449296 & 547195 & 553007 & 561281 & 164.8 \\
& & Households & & & \\
Cattle & 38.0 & 44.5 & 46.2 & 43.7 & 42.7 & 42.4 \\
cows & 47.1 & 50.7 & 49.9 & 46.2 & 45.0 & 44.6 \\
Pigs & 43.6 & 42.9 & 32.6 & 16.1 & 14.5 & 12.6 \\
Sheep and goats & 63.5 & 52.5 & 51.7 & 46.6 & 46.2 & 46.5 \\
sheeps & 58.5 & 48.8 & 48.6 & 43.7 & 43.4 & 43.7 \\
goats & 92.3 & 80.7 & 81.4 & 76.9 & 76.8 & 76.5 \\
Horses & 50.2 & 56.0 & 54.3 & 52.6 & 51.4 & 51.9 \\
Bird & 39.2 & 31.6 & 21.5 & 16.9 & 16.5 & 15.7 \\
Cattle & 2.0 & 4.3 & 7.4 & 11.8 & 12.7 & 13.4 \\
cows & 2.0 & 4.3 & 8.1 & 13.5 & 14.4 & 15.1 \\
Pigs & 2.6 & 4.1 & 4.6 & 2.1 & 2.0 & 1.8 \\
Sheep and goats & 5.9 & 24.5 & 28.0 & 35.9 & 36.8 & 37.0 \\
& & & & & &
\end{tabular}




\begin{tabular}{lcccccc}
\hline Indicators & $2000 \mathrm{y}$. & $2010 \mathrm{y}$. & $2015 \mathrm{y}$. & $2016 \mathrm{y}$. & $2017 \mathrm{y}$. & $\begin{array}{c}2017 \mathrm{y} . \\
\text { in } \% \\
\text { to 2000 y. }\end{array}$ \\
\hline sheeps & 6.2 & 26.3 & 29.9 & 38.1 & 38.9 & 39.0 \\
goats & 4.1 & 10.7 & 9.7 & 13.3 & 13.7 & 15.1 \\
Horses & 4.1 & 8.8 & 16.2 & 24.8 & 26.7 & 27.6 \\
Bird & 0.6 & 0.9 & 1.0 & 1.8 & 1.8 & 1.7 \\
\hline
\end{tabular}

From the data presented in table 2 it follows that in agricultural organizations the proportion of cattle population for the period from 2000 to 2017. decreased from $60 \%$ to $44.2 \%$ (by 15.8 pp), cows - from $50.9 \%$ to $40.3 \%$ (by 10.6 pp), sheep - from $35.3 \%$ to $17.3 \%$ (by $18 \mathrm{pp}$ ), horses - from $45.7 \%$ to $20.5 \%$ (by $25.2 \mathrm{pp}$ ). The share of poultry in agricultural organizations increased from $60.2 \%$ to $82.6 \%$ (by $22.4 \%$ ), pigs from $53.8 \%$ to $85.6 \%$ (by $31.8 \mathrm{pp}$ ), goats - from $3.6 \%$ to $8.4 \%$ (by $4.8 \mathrm{pp}$ ).

In households of the population of the Russian Federation for the period from 2000 to 2017. the share of cattle livestock increased from $38 \%$ to $42.4 \%$ (by $4.4 \mathrm{pp}$ ), the share of horse livestock increased from $50.2 \%$ to $51.9 \%$ (by $1.7 \mathrm{pp}$ ). The share of livestock of cows in the households for the analyzed period decreased from $47.1 \%$ to $44.6 \%$ (by $12.5 \mathrm{pp}$ ), sheep and goats - from $63.5 \%$ to $46.5 \%$ (by $17 \mathrm{pp}$.), including sheep - from $58.5 \%$ to $43.7 \%$ (increased by 17 percentage points), the proportion of the number of goats decreased from $92.3 \%$ to $76.5 \%$ (decreased by $15,8 \mathrm{pp}$ ), the proportion of poultry population in household farms decreased from $39.2 \%$ to $15.7 \%$ (by 23.5 pp). By 2017 , the proportion of cattle livestock in peasant (farmer) farms began to be $13.4 \%$, cows $15 \%$, pigs $-1.8 \%$, sheep and goats $-37 \%$, horses $-27.6 \%$, poultry $-1.7 \%$. Consider the volume of production of main livestock products in the Russian Federation in all categories of farms (table 3).

Table 3. Production of basic livestock products in the Russian Federation in farms of all categories, thousand tons $[1,9]$.

\begin{tabular}{|c|c|c|c|c|c|c|}
\hline Indicators & $2000 \mathrm{y}$. & $2010 \mathrm{y}$ & $2015 \mathrm{y}$. & 2016 y. & $2017 \mathrm{y}$. & $\begin{array}{l}2017 \mathrm{y} . \\
\text { in } \% \\
\text { to } 2000 \mathrm{y} .\end{array}$ \\
\hline $\begin{array}{l}\text { Cattle and poultry for } \\
\text { slaughter } \quad \text { (slaughter } \\
\text { weight) }\end{array}$ & 4445.8 & 7166.8 & 9565.2 & 9899.2 & 10384.4 & 2.3 times \\
\hline cattle & 1897.9 & 1727.3 & 1649.4 & 1619.0 & 1613.6 & 85.0 \\
\hline pigs & 1578.2 & 2330.8 & 3098.7 & 3368.2 & 3529.6 & 2.2 times \\
\hline sheep and goats & 140.3 & 184.6 & 204.5 & 213.1 & 221.8 & 158.1 \\
\hline bird & 767.5 & 2846.8 & 4535.5 & 4620.8 & 4938.6 & 6.4 times \\
\hline Milk & 32259.0 & 31847.3 & 30796.9 & 30758.5 & 31183.5 & 96.7 \\
\hline Eggs, million pieces & 34084.7 & 40599.2 & 42571.7 & 43558.9 & 44890.9 & 131.7 \\
\hline $\begin{array}{l}\text { Wool (in physical } \\
\text { weight), tons }\end{array}$ & 40088 & 53521 & 55644 & 56495 & 56954 & 142.1 \\
\hline Honey, tons & 1197.0 & 1571.0 & 1606.1 & 1650.8 & 1687.5 & 141.0 \\
\hline
\end{tabular}


From the data of table 3 it follows that for the period from 2000 to 2017 in farms of all categories, poultry meat production increased 6.4 times; production of livestock and poultry for slaughter increased by 2.3 times, pig meat - by 2.2 times, wool production increased by $42 \%$, eggs - by $31.7 \%$, honey - by $21.1 \%$. During the analyzed period, the production of cattle meat decreased by $15 \%$, milk production decreased by $3.3 \%$.

Consider the structure of production of main livestock products in the Russian Federation by categories of farms (Table 4 ).

Table 4. Structure of production of basic livestock products in the Russian Federation (as a percentage of total production) $[1,9]$.

\begin{tabular}{|c|c|c|c|c|c|c|}
\hline Indicators & $2000 \mathrm{y}$. & $2010 \mathrm{y}$ & $2015 \mathrm{y}$. & 2016 y. & $2017 \mathrm{y}$. & $\begin{array}{c}2017 \mathrm{y} . \\
\text { in } \% \\
\text { to } 2000 \mathrm{y} .\end{array}$ \\
\hline \multicolumn{7}{|c|}{ Agricultural organizations } \\
\hline $\begin{array}{l}\text { Cattle and poultry for } \\
\text { slaughter (slaughter } \\
\text { weight) }\end{array}$ & 40.2 & 46.2 & 60.6 & 74.5 & 75.9 & 77.4 \\
\hline cattle & 43.0 & 36.2 & 32.7 & 31.9 & 33.1 & 33.7 \\
\hline pigs & 27.6 & 33.2 & 52.7 & 78.2 & 80.7 & 82.5 \\
\hline sheep and goats & 10.8 & 10.7 & 8.9 & 7.9 & 7.5 & 7.0 \\
\hline bird & 65.4 & 78.8 & 88.4 & 91.5 & 91.6 & 92.2 \\
\hline \multicolumn{7}{|c|}{ Households } \\
\hline $\begin{array}{l}\text { Cattle and poultry for } \\
\text { slaughter (slaughter } \\
\text { weight) }\end{array}$ & 58.0 & 51.4 & 36.5 & 22.5 & 21.1 & 19.7 \\
\hline cattle & 55.2 & 60.9 & 62.6 & 60.2 & 58.6 & 57.3 \\
\hline pigs & 70.2 & 64.1 & 44.4 & 20.4 & 18.0 & 16.3 \\
\hline sheep and goats & 85.2 & 80.6 & 72.5 & 70.9 & 70.2 & 69.7 \\
\hline bird & 34.2 & 20.6 & 11.0 & 7.4 & 7.3 & 6.8 \\
\hline \multicolumn{7}{|c|}{ Peasant farms } \\
\hline $\begin{array}{l}\text { Cattle and poultry for } \\
\text { slaughter (slaughter } \\
\text { weight) }\end{array}$ & 1.8 & 2.4 & 2.9 & 2.9 & 2.9 & 2.9 \\
\hline cattle & 1.8 & 2.8 & 4.7 & 7.9 & 8.3 & 8.9 \\
\hline pigs & 2.2 & 2.7 & 3.0 & 1.4 & 1.4 & 1.2 \\
\hline sheep and goats & 4.1 & 8.7 & 18.6 & 21.2 & 22.3 & 23.3 \\
\hline bird & 0.6 & 0.9 & 1.0 & 1.8 & 1.8 & 1.7 \\
\hline
\end{tabular}

From the data of table 4 it follows that for the period from 2000 to 2017. the share of livestock and poultry production for slaughter in agricultural organizations increased from $40.2 \%$ to $77.4 \%$ (by 37.2 percentage points); pigs - from $27.6 \%$ to $82.5 \%$ (by 54.9 pp), poultry - from $65.4 \%$ to $92.2 \%$ (by $26.8 \mathrm{pp}$ ). At the same time, the share of cattle meat production in agricultural organizations decreased from $43 \%$ to $33.7 \%$ (by 9.3 $\mathrm{pp}$ ), and sheep and goat meat - from $10.8 \%$ to $7 \%$ (by $3,8 \mathrm{pp}$ ). 
For the period from 2000 to 2017 the share of livestock and poultry production for slaughter of the population decreased from $58 \%$ to $19.7 \%$ (by $38.3 \mathrm{pp}$ ), pig meat - from $70.2 \%$ to $16.3 \%$ (by 53.9 p. p.), poultry meat - from $34.2 \%$ to $6.8 \%$ (by 27.4 percentage points).

At the same time, there is an increase in the share of cattle meat production in household farms from $55.2 \%$ to $57.3 \%$ (by $2.1 \mathrm{pp}$ ), as well as sheep and goat meat from $85.2 \%$ to $69.7 \%$ (by 15.5 percentage points).

In peasant (farmer) farms, the growth of the share of livestock and poultry production for slaughter by 2017 reached $2.9 \%$, cattle $-8.9 \%$, pigs - $1.2 \%$, sheep and goats $23.3 \%$, birds $-1 \%$.

According to the Ministry of Agriculture of the Russian Federation, the availability of livestock in the Russian Federation (except for pigs and poultry) with feed of its own production in all categories of farms allows organizing uninterrupted feeding of livestock during the winter-stall period, which, in turn, allows high-quality wintering of livestock and complete volume indicators of target indicators of livestock production. Thus, the provision of livestock with rough and succulent feeds for the winter-stall period of 2015-2016 as of January 1, 2016 is $8.5 \mathrm{c}$. fodder units, which is $3.3 \%$ higher than the need. Production and consumption of various types of feed for farm animals in the Russian Federation is 29.5 million tons [3]. At the same time, the need for grain, as the main component of mixed feed, is fully satisfied by domestic raw materials, which completely excludes import dependence.

\section{Conclusions}

- In the Russian Federation for the period from 2000 to 2017. There was an obvious reduction in the number of large livestock and an increase in the number of livestock of small domestic animals. The total number of cattle in the country decreased by about $30 \%$, the number of small animals increased, including: sheep and goats - by $63.7 \%$ (including sheep - by $76 \%$ ), poultry - by $64.8 \%$, pigs - by $46.5 \%$, reindeer by $41 \%$, rabbits -3.1 times.

- In the structure of the concentration of livestock animals, there is a flow of livestock numbers of domestic animals from large-scale to small-scale forms of management: especially cattle, cows, horses from agricultural organizations to peasant (farmer) farms.

- In $2017,44 \%$ of cattle, $85.6 \%$ of pigs, $82.6 \%$ of poultry were concentrated in agricultural organizations. The share of meat products produced in agricultural organizations at the same time for cattle meat was $33.7 \%$, for pig meat $-82.5 \%$, for poultry meat $-92.2 \%$.

- The households of the population in 2017 showed the largest concentration of the number of goats $(76.5 \%)$, horses $(51.9 \%)$, cows $(44.6 \%)$, sheep $(43.7 \%)$.

At present, the polarization of agricultural agri-formations is growing: on the one hand, the number of agricultural holdings is growing, on the other hand, the number of peasant (farmer) farms is increasing. There is a general reduction in the number of large livestock and an increase in the number of livestock of small domestic animals. 
Currently, strategic management decisions are needed to increase the level of food selfsufficiency of the population with meat, milk and meat and dairy products.

\section{References}

1. Agriculture, hunting and forestry. Official site of the Federal State Statistics Service [Electronic resource]. URL: http://www.gks.ru/, last accessed: 2018/10/10.

2. Alcock, D.,,Hegarty, R. S.: Effects of pasture improvement on productivity, gross margin and methane emissions of grazing sheep enterprises. In Second Int. Conf. on Greenhouse Gases and Animal Agriculture, Working Papers (eds C. R. Soliva, J. Takahashi \& M. Kreuzer), pp. 127-130. Zurich, Switzerland: ETH. (2005).

3. Avzalov, M.R., Kuznetsova, A.R.: Development of the dairy cattle industry in the Republic of Bashkortostan // International Journal of Applied and Fundamental Research. 2014. №115, pp. 774-778. (In Russian)

4. Beauchemin, K., McGinn, S.: Methane emissions from feedlot cattle fed barley or corn diets. J. Anim. Sci. 83, pp. 653-661. (2005).

5. China and global beef markets [Internet] Feedlot; 2016. [Cited 2016 Oct 1]. Available from: http://feedlotmagazine.com/china-and-global-beef-markets/, last accessed: 2018/10/28.

6. Delgado, C.: (2005) Rising demand for meat and milk in developing countries: implications for grasslands-based livestock production. In Grassland: a global resource (ed. McGilloway D. A., editor.), pp. 29-39. The Netherlands: Wageningen. (2005).

7. Dijkman, J.: Innovation capacity and the elusive livestock revolution. LINK News Bulletin, October 2009. See: www.innovationstudies.orgwww.innovationstudies.org, last accessed: 2018/10/01.

8. Herrero, M. et al.: Smart investments in sustainable food production: revisiting mixed croplivestock systems. Science 327, 822-825. DOI:10.1126/SCIENCE.1183725. (2010).

9. Information on the state of livestock in 2015. Official website of the Ministry of Agriculture of the Russian Federation [Electronic resource]. Access Mode: http://mcx.ru/documents/document/v7_show/35606.133.htm, last accessed: 2018/10/10.

10. Kabashova, E.V., Kuznetsova, A.R.: Forecasting the average monthly salary of employees using econometric modeling // Russian electronic scientific journal. 2018. №1 (27). C.2646. DOI: 10.31563/2308-9644-2018-27-1-26-45 (In Russian)

11. Kennedy, P.M, Milligan, L.P.: Effects of cold exposure on digestion, microbial synthesis and nitrogen transformation in sheep. Br. J. Nutr. 39, 105-117. (1978).

12. King, D. A., Peckham, C., Waage, J. K., Brownlie, J., Woolhouse, M. E. J.: Infectious diseases: preparing for the future. Science 313, 1392-1393 (DOI:10.1126/SCIENCE.1129134) [PubMed] (2006).

13. Kuznetsova, A.R., Mambetova, L.R., Valiyeva, G.R., Kadyrov, E.M.: Problems of ensuring food security of the Republic of Bashkortostan // Economics of Agriculture of Russia. 2014, №10, pp.38-45. (In Russian)

14. Kuznetsova, A.R., Zagirova, Z., Omarhanova, Zh.: Problems of agriculture and agriculture. In the collection: Hradec Econiomic Days Double-blind Meeting of the Economic Days 2018, pp. 523-538.

15. Machmülller, A., Ossowski, D.A., Kreuzer, M.: Comparative evaluation of the effects of coconut oil, oilseeds and crystalline fat on methane release, digestion and energy balance in lambs. Anim. Feed Sci. Technol. 85, pp. 41-60. DOI:10.1016/S0377-8401(00)001267. (2000). 
16. Murray R.M., Bryant A.M., Leng R.A.: Rate of production of methane in the rumen and the large intestine of sheep. Br. J. Nutr. 36, pp. 1-14. DOI:10.1079/BJN19760053. (1976).

17. Thornton, P.K.: Livestock production: recent trends, future prospects. Sep 27; 365(1554): 2853-2867. DOI: 10.1098/rstb.2010.0134. (2010).

18. Xiang, Zi Li., Chang, Guo Yan, Lin, Sen Zan: Current situation and future prospects for beef production in China - A review // Asian-Ausralas J Anim Sci. 2018 Jul; 31 (7), pp. 984-991. DOI: 10.5713/ajas.18.0212. (2018). 